http:/www.journals.zu.edu.eg/journalDisplay.aspx?Journalld=1\&queryType=Master

\title{
EVALUATION OF PHYSICO-CHEMICAL PROPERTIES OF SOME MIXTURE JUICES
}

\author{
Soheir E.M. Saad ${ }^{*}$ \\ Hort. Crops Tech. Res. Dept. Food Tech. Res. Ins. Agric. Res. Cent., Giza, Egypt
}

Received: 22/02/2017 ; Accepted: 21/03/2017

\begin{abstract}
This study was carried out to investigate improving and developing mixed fruit juices prepared from mango, strawberry, pineapple, orange, and pomegranate with different ratios as well as having nutritional values with highly functional and organoleplicolly characteristics. Development of new technologies for thermal food treatment is still of great industrial and scientific interest. Microwave heating is one of these new technologies. The fruits blended juices were pasteurized by two different methods, i.e. conventional processing at $80^{\circ} \mathrm{C}$ for $10 \mathrm{~min}$ and microwave heating $(2450 \mathrm{MHz})$ using $100 \%$ and $70 \%$ capacity for $3 \mathrm{~min}$. After thermal processing, juices were stored at $4^{\circ} \mathrm{C}$ and analyzed after processing and storage. The physicochemical parameters studied were $\mathrm{pH}$ value, total soluble solids (TSS) and titratable acidity (TA) along with an estimate of metal elements such as iron, potassium, calcium, phosphorus, zinc. These juice mixtures were analyzed for their (vitamin $\mathrm{C}$, antioxidant total phenolic and total flavonoid). The obtained results revealed that fresh strawberry has high content of antioxidant activity (\%), total phenolic, total flavonids followed by fresh pomegranate and pineapple, respectively. Meanwhile fresh mango was higher in total soluble solids (TSS) and pH value and as well as lowest in titratable acidity (TA). Factors affecting physical, and chemical and quality of juices were studied after processing and storage as well as microbiological evaluation. Results showed no presence of viable microorganisms (total count, mold and yeast) after storage at $4^{\circ} \mathrm{C}$ in all treatments. Also results showed that conventional treatment led to a significant decrease in vitamin $\mathrm{C}$ and total anthocyanins while microwave pasteurization preserved these compounds. Also it found that microwave pasteurization at 100\% capacity recorded the highest values in each of antioxidant activity, total phenolic, total flavonids and total soluble solids (TSS) compared to pasteurization on the capacity of $70 \%$.
\end{abstract}

Key Words: Mango, strawberry, pineapple, orange, pomegranate, microwave and conventional pasteurized, chemical, physical properties.

\section{INTRODUCTION}

Fruits and vegetables are necessary for good health and for all age categories as these are important portion of a healthy diet. The importance and nutritional quality of fruits are due to colour, unique taste, smell, enriched minerals, vitamins and other beneficial components, Cassano et al. (2003). Fruits like apple, pomegranate, grapes, orange, blueberries, cranberries, gooseberries, strawberries and carrots are the major sources of bioactive compounds and antioxidant also.

\footnotetext{
* Corresponding author. Tel. : +201222806581

Email address: soheir77099@yahoo.com
}

The pomegranate (Punica granatum) lie among the most popular fruits in Egypt. Such fruit is cultivated in tropical and subtropical areas and widely consumed by people in many countries. Pomegranate is considered to be very rich source for nutrients and anthocyanins. Hong et al. (2008) reported that the total soluble solids varied between $13-16 \%$.

Orange (Citrus cinensis) is a widely consumed fruit, mainly used for its fresh flavour and it is a very good source of natural antioxidant and possess health benefits due to the presence of antioxidants like vitamin-C, Campos et al. (2010). 
Strawberry fruits are excellent raw material for juice production, as they contain numerous antioxidants including phenolic compounds, vitamin $\mathrm{C}$, and minerals. Their healthpromoting properties include anti-oxidative activity (Borowska et al., 2009).

Mango is one of the most delicious tropical fruits of the world. It is an excellent source of fiber, carbohydrate, carotene (pro- vitamin A), vitamin $\mathrm{C}, \mathrm{B}$ complex and minerals (iron, and phosphorus) Akhter et al. (2012).

Pineapple (Ananas comosus) has long been one of the most popular of the non-citrus tropical and subtropical fruits around the world, largely because of its attractive flavour and refreshing sugar-acid balance and is consumed as fresh fruits and juice. Pineapple was reported to contain polyphenolic compounds and also possess antioxidant activity Hossain and Rahman (2011). Studies showed that compounds such as phenolics and flavonoids are responsible for providing antioxidant activity. Raw pineapple juice contains almost all vitamins and minerals essential for the digestive system. Pineapple juice contains a mixture of protein-digesting enzymes called bromelain. Bromelain is an antiinflammatory agent. Juice extracted from pineapple can be processed into many forms such as concentrated juice, mixed juice and single strength juice (Mhatre et al., 2009).

Production of fruit beverages on a commercial scale was practically unknown till about 1930 , but since then it has gradually become an important industry. Fruit beverages are easily digestible, highly refreshing, thirst quenching, appetizing and nutritionally far superior to many synthetic and aerated drinks (Akash et al., 2014).

Juices are important and integral part of a healthy diet and are highly recommended for the nutritional content, phytochemical value and the presence of health promoting compounds. Juices are also rich sources of vitamin C, carotenoids, flavonoids, dietary fiber and phytochemicals etc. Ascorbic acid and water soluble polyphenols are the main antioxidants present in various juices (Piljac-Zegrac et al., 2009). Providing health promotingproperties to the juices. These also contribute to the flavour and colour attributes of the fruits. Cullen et al. (2010) found that fruit juice is a popular beverage because it is an important source for bioactive compounds including vitamins, phenolic compounds, anthocyanins and carotenoids.

De Carvalho et al. (2007) reported that the blending of the juice is the best methods to enhance the nutritional quality and the vitamin and mineral content of the juice depend on the types of fruits and vegetables used. Thus blendeding drinks are a good method to the development of new products which gives new taste and improvement in the quality of nutrition. This improvement can be attributed to the mix of two or more kinds of fruit juices.

Pasteurization is the most widely used technology for killing pathogenic and spoilage microorganisms in milk and fruit juices; however, it may largely destroy the organoleptic, nutritional value and physiochemical characteristics of food. Safe and minimally processed foods with high quality attributes are essential to satisfy consumer needs, and those traits encourage those in the food and academic industries for finding innovative food processing techniques (Riahi and Ramaswamy, 2004).

Microwave heating refers to the use of electromagnetic waves of certain frequencies to generate heat in a material. Typically, microwave food processing uses the 2 frequencies of 2450 and $915 \mathrm{MHz}$ of these two, the $2450 \mathrm{MHz}$ frequency is used for home ovens, and both are used in industrial heating. For protecting nutritional and sensory quality characteristics of foods during processing, new techniques, such as electrical methods, are improved as alternatives to traditional methods. They aim to inactivate enzymes and kill microorganisms in a short time rather than thermal processes while minimizing quality losses. Microwave (MW) heating is another electrical method that provides inactivation of microorganisms quickly rather than the traditional heating methods (Ahsen and Baysal, 2011). MW heating can be used in the food industry for blanching, cooking, pasteurization, and preheating. Recent studies show that (MW) heating also provides the transfer of functional components to a product (Gerard and Roberts, 2004).

Microwave heating (MW) appears to be a promising novel technology for food preservation. During recent decades, many 
studies have been carried out on the evaluation of (MW) benefits with respect to conventional heat treatments. Its suitability for pasteurization, sterilization, and dehydration processes as well as its capacity of producing safe and better quality products has been widely demonstrated (Igual et al., 2010). Although (MW) could potentially replace conventional heat processes for some specific applications.

Several studies have successfully been carried out into the microwave pasteurization of fruit juices, as it preserves the natural organoleptic characteristics of the juice and reduces the time of exposure to energy, with the subsequently lower risk of losing essential thermo labile nutrients (Caoumir et al., 2002). These fruits are usually consumed in fresh form juices, beverage, jams and concentrated.

Thus objectives of this study were to evaluate the effect of using of pasteurization microwave at two power levels on the physical-chemical properties, as well as total soluble solids (TSS), $\mathrm{pH}$ value, phenolic compound, antioxidant activity and microbial activity in mixture juices, and to compare these results against a conventional pasteurization, and preparing a new juice with quite acceptable flavour and aroma.

\section{MATERIALS AND METHODS}

\section{Raw Materials}

Oranges (variety: Balady), mango (variety: kent) pineapple (Ananas comosus), pomegranate (Punica granatum L.). strawberry (Fragaria $\times$ ananassa) were purchased from a local market from Cairo in 2015

\section{Method of Production of Mixed Fruit Juice}

\section{Preparation of juices}

Mango, pineapple, strawberry, pomegranate and oranges were extracted from the above mentioned fruits after washing with water as follows:

\section{Pineapple}

The shell and core of pineapple were removed using sharp stainless steel knife the flesh was cut into small pieces and the juice was extracted.

\section{Pomegranate}

The top and bottom of the pomegranate husks were removed with a sharp stainless steel knife and cut into halves and then the arils were separated and used for the extraction of the arils juice.

\section{Mango}

Mango had peeled and the flesh separated from the stone using a kitchen knife and cut into pieces.

\section{Strawberry}

Strawberry was sorted and the green part was carefully removed.

\section{Oranges}

Oranges were cut into halves, oranges were squeezed with fruit juicer (Kenwood multi processor FPP230 750W).

The mango, strawberry, pineapple, pomegranate juice is extracted them using fruit juice extractor (brand Moulinex- Power with 800W Motor, 2 speed) electronic controls for juicing soft and hard fruit, The juicer has a capacity of $2 \mathrm{~kg}$ for processing the pulp and $1 \mathrm{~L}$ for processing of juice. The stainless steel micro mesh filter basket in the juicer separates juice and pulp and produces clean, fresh juice every time. The extracted juices were filtrated through a double layers of muslincloth then the juices were blended in different ratios and the total soluble solids (TSS) was measured. The results was $16 \%, 11 \%$ and $12.5 \%$ for juices $\mathrm{A}, \mathrm{B}$ and $\mathrm{C}$, respectively. In juice $\mathrm{A}$, no sugar was added while in juice $\mathrm{B}$ and $\mathrm{C}$ sugar was added up to $14 \%$ (TSS).

\section{Thermal pasteurization treatments}

\section{Conventional thermal treatment}

Thermal pasteurization was performed by heating the mixed juice at $80^{\circ} \mathrm{C}$ for $10 \mathrm{~min}$. The temperature of the juice during the heating process was monitored using a thermocouple. The pasteurized juices were filled in sterilized bottles and capped with sterilized caps. Then all the samples were cooled and stored at refrigerated temperature $4^{\circ} \mathrm{C}$ for 3 months. 
Table 1. Preparation of juice formulas from different fruits with different ratios

\begin{tabular}{|c|c|c|c|c|c|c|}
\hline \multirow[t]{2}{*}{ Treatment } & \multicolumn{5}{|c|}{ Juice component } & \multirow[t]{2}{*}{ Notes } \\
\hline & Mango & Orange & Pomegranate & Strawberry & Pineapple & \\
\hline $\mathbf{T 1}$ & $\sqrt{ }$ & $\sqrt{ }$ & $\sqrt{ }$ & $x$ & $x$ & $\begin{array}{l}\text { microwave pasteurization at } \\
100 \% \text { capacity }\end{array}$ \\
\hline $\mathbf{T 2}$ & $\sqrt{ }$ & $\sqrt{ }$ & $\sqrt{ }$ & $x$ & $x$ & $\begin{array}{l}\text { Microwave pasteurization at } \\
70 \% \text { capacity }\end{array}$ \\
\hline T3 & $\sqrt{ }$ & $\sqrt{ }$ & $\sqrt{ }$ & $x$ & $x$ & Conventional pasteurized \\
\hline T4 & $x$ & $\sqrt{ }$ & $\sqrt{ }$ & $\sqrt{ }$ & $x$ & $\begin{array}{l}\text { microwave pasteurization at } \\
100 \% \text { capacity }\end{array}$ \\
\hline T5 & $x$ & $\sqrt{ }$ & $\sqrt{ }$ & $\sqrt{ }$ & $x$ & $\begin{array}{l}\text { microwave pasteurization at } \\
70 \% \text { capacity }\end{array}$ \\
\hline T6 & $x$ & $\sqrt{ }$ & $\sqrt{ }$ & $\sqrt{ }$ & $x$ & Conventional pasteurized \\
\hline T7 & $x$ & $\sqrt{ }$ & $\sqrt{ }$ & $\sqrt{ }$ & $x$ & $\begin{array}{l}\text { microwave pasteurization at } \\
100 \% \text { capacity added } 1 \% \\
\text { butter }\end{array}$ \\
\hline T8 & $x$ & $\sqrt{ }$ & $\sqrt{ }$ & $x$ & $\sqrt{ }$ & $\begin{array}{l}\text { microwave pasteurization at } \\
100 \% \text { capacity }\end{array}$ \\
\hline T9 & $x$ & $\sqrt{ }$ & $\sqrt{ }$ & $x$ & $\sqrt{ }$ & $\begin{array}{l}\text { microwave pasteurization at } \\
70 \% \text { capacity }\end{array}$ \\
\hline T10 & $x$ & $\sqrt{ }$ & $\sqrt{ }$ & $x$ & $\sqrt{ }$ & Conventional pasteurized \\
\hline
\end{tabular}

Where :

T1- $40 \%$ mango, $30 \%$ orange, $30 \%$ pomegranate .

T3- $40 \%$ mango, $30 \%$ orange, $30 \%$ pomegranate

T5- $40 \%$ strawberry, $30 \%$ orange, $30 \%$ pomegranate .

T7- $40 \%$ strawberry, $30 \%$ orange, $30 \%$ pomegranate .

T9- $40 \%$ pineapple , $30 \%$ orange , $30 \%$ pomegranate .

\section{Microwave treatment}

Mixed juices were pasteurized was carried out in a $1100 \mathrm{~W}$ microwave oven operating at $2450 \mathrm{MHz}$ (model SHARP R-340R (S). Cavity dimensions of the microwave oven were 22.6 $\mathrm{cm}$ high, $37.5 \mathrm{~cm}$ wide and $38.7 \mathrm{~cm}$ long. Two power levels have been used for the pasteurization of juice are $100 \%$ and $70 \%$. Juice $(250 \mathrm{ml})$ was transferred into a cylindrical beaker clean $800 \mathrm{ml}$, the beaker was covered cup hour, and placed in the middle of the MW oven. Time of pasteurization was 3 minutes for both power levels to hold the temperature, beaker were kept inside the oven cavity with rotation, at energy level 0 (without power).

Immediately after pasteurized juices were filled in sterilized bottles with hot and lock
T2- $40 \%$ mango, $30 \%$ orange, $30 \%$ pomegranate.

T4- $40 \%$ strawberry, $30 \%$ orange, $30 \%$ pomegranate.

T6- $40 \%$ strawberry, $30 \%$ orange, $30 \%$ pomegranate.

T8- $40 \%$ pineapple, $30 \%$ orange, $30 \%$ pomegranate.

T10- $40 \%$ pineapple, $30 \%$ orange, $30 \%$ pomegranate.

stopper. Then all the samples were cooled and stored at refrigerator temperature at $4^{\circ} \mathrm{C}$ till analysis.

\section{Storage of juice}

Microwave, thermally pasteurized juices were stored at refrigeration temperature of $4^{\circ} \mathrm{C}$ for three months after processing.

\section{Analyticl Methods}

\section{Chemical analysis}

Moisture, total soluble solids (TSS), $\mathrm{pH}$ value, total titratable acidity, ash content, LAscorbic acids and mineral content (iron, potassium, calcium, phosphorus and zinc )were determined by Atomic Absorption spectrophotometer according to the method of AOAC (2012). 


\section{Determination of total phenolic compounds (TPC)}

Total phenolic compounds (TPC) were determined by the Folin- Cicalteau method as described by Singleton et al. (1999), with minor modifications, based on colorimetric oxidation/ reduction reaction of phenols. Gallic acid was used for calibration curve. Results were expressed as mg Gallic acid (GAE).

\section{Determination of total flavonoids}

Total flavonoids content was measured by using aluminum chloride calorimetric method, as described by Chang et al. (2002). The results were expressed as catechin equivalents (CE) in $\mathrm{mg} / 100 \mathrm{~g}$.

\section{Determination of antioxidant activity}

The antioxidant activity of free and bound phenolic extracts was measured by using 1, 1diphenyl-2-picrylhydrazyl (DPPH) scavenging as previously described by Hung and Morita (2009).

\section{Determination of total anthocyanins}

Total monomeric anthocyanin pigment was extracted and determined according to the method described by Robert and Wrolstad (2005).

\section{Microbial analysis}

Microbial analysis was carried out as shown by Rivas et al. (2006). For the microbial counts, samples were serially diluted, plated in total count agar (PCA) for total plate (aerobic) counts, and in acidified Potato dextrose agar (PDA) for molds and yeast counts. Plates were incubated at $30 \mathrm{C}$ for $48 \mathrm{hr}$., for total plate counts and molds and yeast respectively.

\section{RESULTS AND DISCUSSION}

\section{Physico-Chemical Parameters of Fresh Fruit Juices}

The physico-chemical parameters of fresh fruit juices are presented in Table 2, results in Table 2 indicate that moisture content was low in mango fresh juice (79.14\%) and high in strawberry $(90.70 \%)$. While the percentage of moisture in pineapple, orange and pomegranate juices were $86.54,87.31$ and $83.16 \%$, respectively.
The total soluble solids (TSS) content was significantly influenced by the combined effect of maturity stages. Total soluble solids (TSS) content of mango and pomegranate juices in this study were higher than those of other juices. The lowest total soluble solids (TSS) was shown in strawberries juice, while total soluble solids (TSS) were equally in orange and pineapple juices (Table 2).

A reverse in values was observed for titratable acidity wherein orange juice having the highest value of $0.896 \%$ followed by pineapple juice $(0.832 \%)$ while the lowest value of 0.224 was in mango juice.

As for the total ash, the ratios were 0.370 , $0.326,0.290,0.378$ and 0.434 for mango, strawberry, pineapple, oranges and pomegranates, respectively.

As it is clear from Table 2, Vitamin-C was found to be maximum $(55.75 \mathrm{mg} / 100 \mathrm{ml})$ in strawberry juice followed by orange juice which had $43.85 \mathrm{mg} / 100 \mathrm{ml}$ and decremental order by pomegranate $(3415 \mathrm{mg} / 100 \mathrm{ml})$, pineapple $(28.52$ $\mathrm{mg} / 10 \mathrm{0ml})$ and mango $(18.78 \mathrm{mg} / 100 \mathrm{ml})$.

Fruit juices have a low $\mathrm{pH}$ values because they are comparatively rich in organic acid. In this study, the $\mathrm{pH}$ values of the fruit juices varied from 3.342 to 4.241 . The highest $\mathrm{pH}$ values was shown by mango juice 4.241, followed by pomegranate juice 3.954 and the lowest was in pineapple juice (3.342).

The results for antioxidant activity (\%), total phenolic and total flavonoids in fresh juices are presented in the same table. The values of total antioxidant activity (\%) varied from $28.18 \%$ to $91.52 \%$ in the different juice obtained in the present work. High antioxidant activity (\%) was observed in strawberry $91.52 \%$ followed by Pomegranate $85.24 \%$, while pineapple antioxidant activity was $73.31 \%$. As well as, it was $56.36 \%$ and 28.15 in orange and mango juices, respectively.

As shown in Table 2, values for total phenolic content in fresh juices varied from 42.03 to $220.62(\mathrm{mg} / 100 \mathrm{ml})$. The highest total phenolic content was obtained in strawberry juice $220.62(\mathrm{mg} / 100 \mathrm{ml})$, followed by pomegranate $(172.68 \mathrm{mg} / 100 \mathrm{~g})$. The lowest total phenolic content was in mango juice. The results 
Table 2. Physico-chemical properties composition of fresh juices mango, strawberry, pineapple, orange and pomegranate

\begin{tabular}{lccccc}
\hline Constituents & \multicolumn{5}{c}{ Raw materials } \\
\cline { 2 - 6 } & Mango & Strawberry & Pineapple & Orange & Pomegranate \\
\hline Moisture (\%) & 79.14 & 90.70 & 86.54 & 87.31 & 83.16 \\
TSS (\%) & 18.5 & 8 & 11 & 11 & 16 \\
Titrable acidity (\%) & 0.224 & 0.448 & 0.832 & 0.896 & 0.512 \\
Total ash (\%) & 0.370 & 0.326 & 0.290 & 0.378 & 0.434 \\
Vitamin (C) $\mathbf{m g / ~ 1 0 0 ~ m l ~}$ & 18.78 & 55.75 & 28.52 & 43.85 & 34.15 \\
pH value & 4.241 & 3.537 & 3.342 & 3.650 & 3.954 \\
Antioxidant activity (\%) & 28.18 & 91.52 & 73.31 & 56.36 & 85.24 \\
Total phenolic (mg/ 100 ml) & 42.03 & 220.62 & 73.77 & 80.34 & 172.68 \\
Total flavonoids (mg/ 100ml) & 23.82 & 73.50 & 19.46 & 17.93 & 45.07 \\
\hline
\end{tabular}

of total flavonoids content in fresh juices for strawberries and pomegranate had higher total flavonoids content compared to mango, pineapple and orange. These results are agreement with the (Punna and Paruchuri, 2003; Dharti and Dhvanika, 2014; Manoj et al., 2014; Emy et al., 2015; Ohwesiri et al., 2016).

\section{Mineral Content in Fresh Fruit Juices (mg/l)}

The content of $\mathrm{Fe}, \mathrm{K}, \mathrm{Ca}, \mathrm{P}$ and $\mathrm{Zn}$ in fresh fruit juices are presented in Table 3 and Fig. 1. Results in Table 3 and Fig. 1 ascertained that fresh pomegranate juice, had the highest content of potassium $(1855 \mathrm{mg} / \mathrm{l})$ followed by mango juice $(1444 \mathrm{mg} / \mathrm{l})$ and the lowest was pineapple juice $(688.7 \mathrm{mg} / \mathrm{l})$. While calcium, phosphorus and iron in fresh orange juice were $81.96,155.3$ and $2.694 \mathrm{mg} / 1$, respectively. Iron content in fresh strawberry juice recorded the highest value $(2.999 \mathrm{mg} / \mathrm{l})$ while the lowest iron content was obtained in mango juice $(2.053 \mathrm{mg} / \mathrm{l})$. As for zinc content it was not detected under the applied the assay method in all juices. These results are in agreement with those reported by (Fuglie, 2001; Ahuja et al., 2012; Mustafa and Mehmet, 2012).

Mineral content in the mixes fresh juices before processing, are presented in Table 4 and
Fig. 2 It could be seen that higher contents of iron $(4.283 \mathrm{mg} / \mathrm{l})$ in mixes juices (B) followed by mixes juices (A) and were relatively low in mixes juices (C), while juices mixes (A) had highest content in each of potassium, calcium and phosphorus were 1586, 90.87 and 147.2 $\mathrm{mg} / \mathrm{l}$, respectively.

On the other hand it was found that no largely difference in calcium content in the mixes juices (A, B and C) which were 90.87, 85.56 and $88.78 \mathrm{mg} / \mathrm{l}$, respectively. Similar results concerning phosphorus contents were reported in mixes juices (A) and (B), respectively and lowest was in mixes juices $(\mathrm{C})$.

The content of $\mathrm{Fe}, \mathrm{K}, \mathrm{Ca}, \mathrm{P}$ and $\mathrm{Zn}$ in juices mixes after pasteurization are shown in Fig. 3, from the Figure it could be indicated that the Fe concentration was varying in all treatments, and the highest concentration observed in treatments containing strawberry juice followed by treatments containing pineapple juice and finally in treatments containing mango juice. In contrast the highest content of $\mathrm{K}$ was found in treatments pasteurization by microwave at two power levels compared with conventional pasteurization. On the other hand, samples containing mango juice were higher in potassium, followed by samples containing pineapple juice 
Table 3. Mineral content in fresh fruit juices $(\mathrm{mg} / \mathrm{l})$

\begin{tabular}{lccccc}
\hline Raw Material & \multicolumn{5}{c}{ The element (mg/l) } \\
\cline { 2 - 6 } & $\mathbf{F e}$ & $\mathbf{K}$ & $\mathbf{C a}$ & $\mathbf{P}$ & Zn \\
\hline Mango & 2.053 & 1444.0 & 80.05 & 148.3 & ND \\
Strawberry & 2.999 & 1104.0 & 92.15 & 120.2 & ND \\
Pineapple & 2.831 & 688.7 & 107.0 & 36.61 & ND \\
Orange & 2.694 & 1422.0 & 81.96 & 155.3 & ND \\
Pomegranate & 2.243 & 1855.0 & 57.41 & 111.0 & ND \\
\hline
\end{tabular}

$\mathrm{ND}=$ Not detected under the applied the assay method.

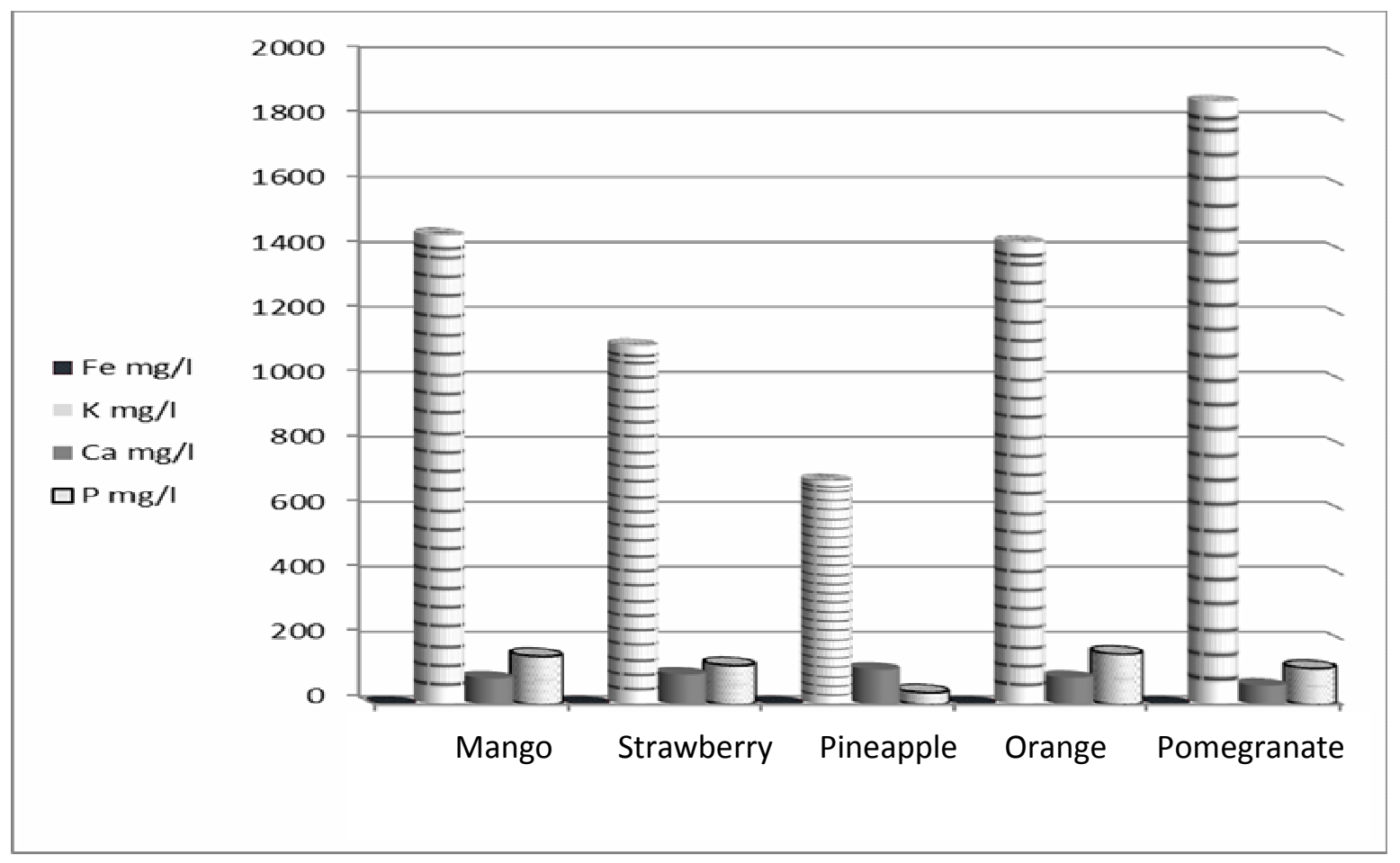

Fig. 1. Mineral content in mango, strawberry, pineapple, orange and pomegranate

Table 4. Elements content in the mixtures of fresh juices

\begin{tabular}{ccccccc}
\hline Symbol & Mixture juice & \multicolumn{5}{c}{ The element (mg/l) } \\
\cline { 3 - 7 } & & Fe & K & Ca & P & Zn \\
\hline A & Mango+ O + P & 2.712 & 1586.0 & 90.87 & 147.2 & ND \\
B & Strawberry + O + P & 4.283 & 1548.0 & 85.56 & 143.9 & ND \\
C & Pineapple + O + P & 2.556 & 1555.0 & 88.78 & 90.30 & ND \\
\hline
\end{tabular}

$\mathrm{ND}=$ Not detected under the applied the assay method. $\quad \mathrm{O}=$ orange juice $; \mathrm{P}=$ pomegranate juice. 


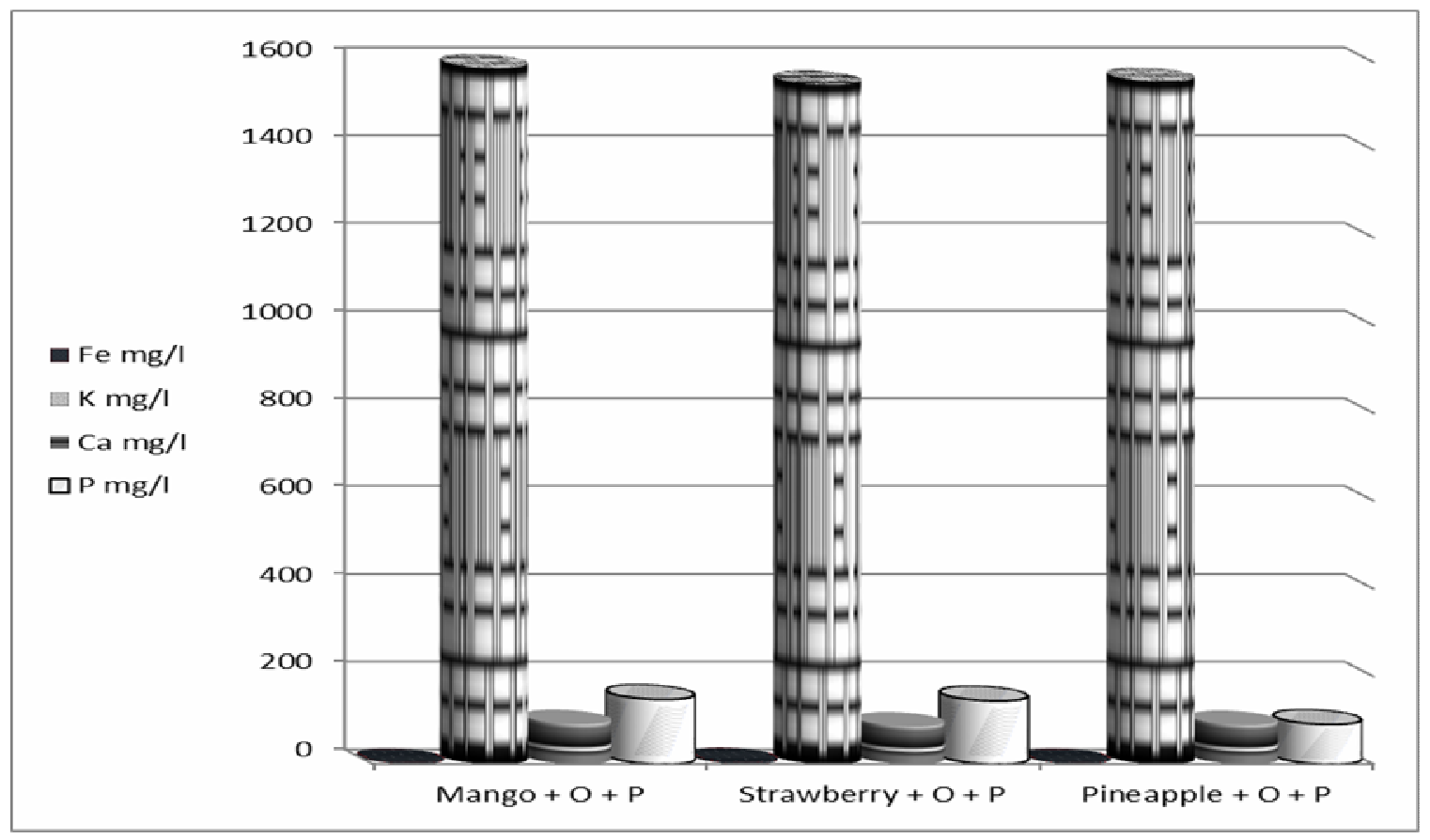

Fig. 2. Mineral content in the mixture of fresh juices

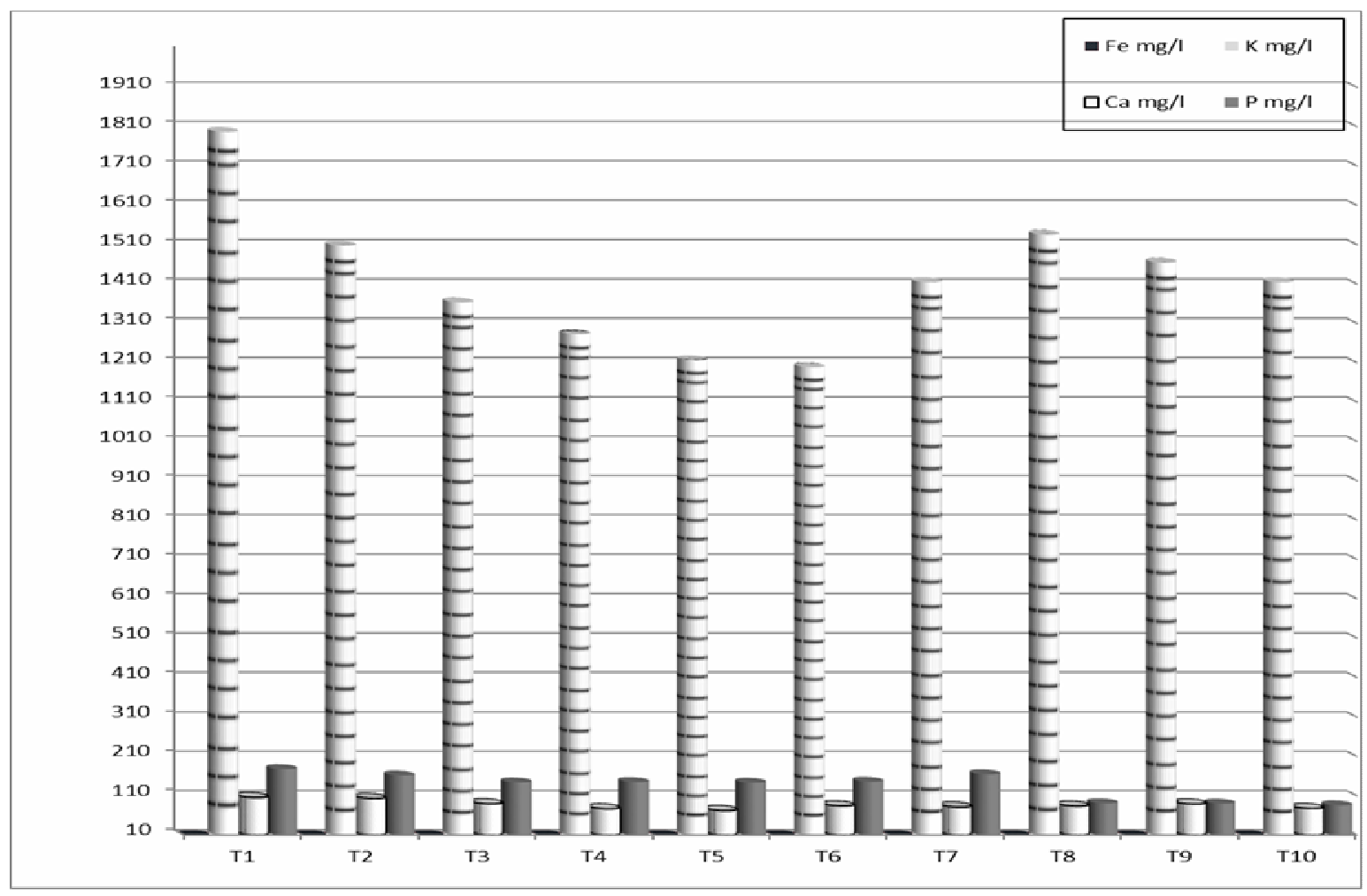

Fig. 3. Mineral content in the mixture fruit juice after pasteurization 
and a lower in the samples containing strawberry juice, of the same shape it could be noticed the highest concentrations of $\mathrm{Ca}$ in juices mixes of treatments containing mango juice followed by treatments containing pineapple juice and finally in treatments containing strawberry juice. While phosphor was the highest in treatments containing mango juice followed by treatments containing strawberry juice and the lowest was in treatments containing pineapple juice.

Effect of different methods of pasteurization and storage on total soluble solid (TSS), $\mathrm{pH}$ value and total titratable acidity of mixture fruit juices.

Results in Table 5 show the physical and chemical properties of juice mixtures after pasteurization and storage at $4{ }^{\circ} \mathrm{C}$. The $\mathrm{pH}$ value of the mixture fruit juices varied from 3.615 to 3.876. The highest $\mathrm{pH}$ value was shown by treatment T1 (3.876) and the lowest was given by treatment $\mathrm{T} 9(3.615)$.

In all juice mixture no changes were observed during the storage. It leads to maintain good quality of juices. A similar study that described the $\mathrm{pH}$ of thermally processed Valencia and Navel orange juice found no significant modifications throughout the storage Bull et al. (2004), Rivas et al. (2006) also reported no $\mathrm{pH}$ variations in thermally treated juice (blended orange and carrot juice) during storage.

Total titratable acidity varied in different types of mixture fruit juices (Table 5). Maximum acidity was found in the treatment T9 containing (40\% pineapple $30 \%$ orange and $30 \%$ pomegranate juice) which was $0.768 \%$ due to more acidic than other treatment. Awsi and Er. Dorcus (2012), reported that the titratable acidity content of pineapple and orange juice with different ratio vary from 0.83 to 0.54 , which is similar to the present study. While minimum acidity was found in the treatment T3 $(0.48 \%)$. Similar results were found by Igual et al. (2010), who showed that microwave heating did not have an effect in citric acid content. However, data reported by Yeom et al. (2000) did not find changes in $\mathrm{pH}$ of orange juice treated by PEF and stored for 112 days at $4^{\circ} \mathrm{C}$.
Total Soluble Solids (TSS) content of mixture fresh juices before pasteurization in this study were $(16 \%, 14 \%$ and $14 \%)$ in treatments $\mathrm{A}, \mathrm{B}$, and $\mathrm{C}$ respectively. The total Soluble Solids (TSS) content of microwave and conventional processing mixture juice fruits were higher than the control in all treatments. The total soluble solids (TSS) content of T1, T2, and $\mathrm{T} 3$ were $19 \%, 17.5 \%$ and $17 \%$, respectively. (MW) also showed a highest in total soluble solids (TSS) compared to conventional processing and power level have a significant effect on total soluble solids (TSS) after processing.

The total soluble solids (TSS) remained almost invariable and no changes were observed during the storage. According to Tandon et al. (2003) the higher soluble solids of pasteurised juice are due to water evaporation during thermal pasteurizing in the steam jacketed kettle. also reported no significant changes in the total soluble solids during storage Bull et al. (2004). $\mathrm{He}$ also reported that the ${ }^{\circ}$ Brix of thermally processed orange juice did not change significantly during storage time.

\section{Phytochemical Content of Mixes Fresh Juices}

Results are shown in Fig. 4 it could be observed that there were higher contents of antioxidant activity (\%) in juice mixes (B) followed by mixes juice (C) and were low in mixes juice (A). The same trend was observed in total phenolic $(\mathrm{mg} / 100 \mathrm{ml})$, total anthocyanin $(\mathrm{mg} / 100 \mathrm{ml})$ and Vitamin C (mg/100ml). Total flavonoids $(\mathrm{mg} / 100 \mathrm{ml})$ had highest in mixes juice (B) followed by mixes juice (A) and were relatively low in mixes juice (C).

\section{Effect of Pasteurization Process and Storage on the Antioxidant, Total Phenolic and Total Flavonoid Contents of Juices Mixture}

The changes in the antioxidant, total phenolic and total flavonoid contents of juice mixes treated with microwave pasteurization at two power level have been used $(100 \%$ and $70 \%$ capacity) and conventional pasteurization after processing and storage have been show in Table 6 . It could be seen that the total phenolic content decrease in all treatments after pasteurization as 
Table 5. Effect of different methods of pasteurization and storage on total soluble solid (Brix), pH value and total titratable acidity of mixture juices

\begin{tabular}{ccccccc}
\hline Treatment & $\begin{array}{c}\text { pH value } \\
\text { after } \\
\text { processing }\end{array}$ & $\begin{array}{c}\text { pH value } \\
\text { after } \\
\text { storage }\end{array}$ & $\begin{array}{c}\text { Total titratable } \\
\text { acidity (as citric } \\
\text { acid) }(\%) \text { after } \\
\text { processing }\end{array}$ & $\begin{array}{c}\text { Total titratable } \\
\text { acidity (as citric } \\
\text { acid) (\%) after } \\
\text { storage }\end{array}$ & $\begin{array}{c}\text { TSS (\%) } \\
\text { after } \\
\text { processing }\end{array}$ & $\begin{array}{c}\text { TSS (\%) } \\
\text { after } \\
\text { storage }\end{array}$ \\
\hline T1 & 3.876 & 3.862 & 0.485 & 0.490 & 19 & 19 \\
T2 & 3.869 & 3.860 & 0.482 & 0.485 & 17.5 & 17.5 \\
T3 & 3.796 & 3.792 & 0.480 & 0.487 & 17 & 17 \\
T4 & 3.695 & 3.685 & 0.640 & 0.645 & 15.5 & 15.5 \\
T5 & 3.768 & 3.762 & 0.670 & 0.676 & 15.5 & 15.5 \\
T6 & 3.738 & 3.732 & 0.655 & 0.662 & 15 & 15 \\
T7 & 3.779 & 3.768 & 0.682 & 0.687 & 17 & 17 \\
T8 & 3.628 & 3.620 & 0.704 & 0.711 & 16 & 16 \\
T9 & 3.620 & 3.615 & 0.768 & 0.775 & 15 & 15 \\
T10 & 3.609 & 3.600 & 0.750 & 0.758 & 15 & 15 \\
\hline
\end{tabular}

T1- $40 \%$ mango, $30 \%$ orange, $30 \%$ pomegranate.

T3- $40 \%$ mango, $30 \%$ orange, $30 \%$ pomegranate.

T5- $40 \%$ strawberry, $30 \%$ orange, $30 \%$ pomegranate.

T7- $40 \%$ strawberry, $30 \%$ orange, $30 \%$ pomegranate.

T9- $40 \%$ pineapple, $30 \%$ orange, $30 \%$ pomegranate.
T2- $40 \%$ mango, $30 \%$ orange, $30 \%$ pomegranate.

T4- $40 \%$ strawberry, $30 \%$ orange, $30 \%$ pomegranate.

T6- $40 \%$ strawberry, $30 \%$ orange, $30 \%$ pomegranate.

T8- $40 \%$ pineapple, $30 \%$ orange, $30 \%$ pomegranate.

T10- $40 \%$ pineapple, $30 \%$ orange, $30 \%$ pomegranate

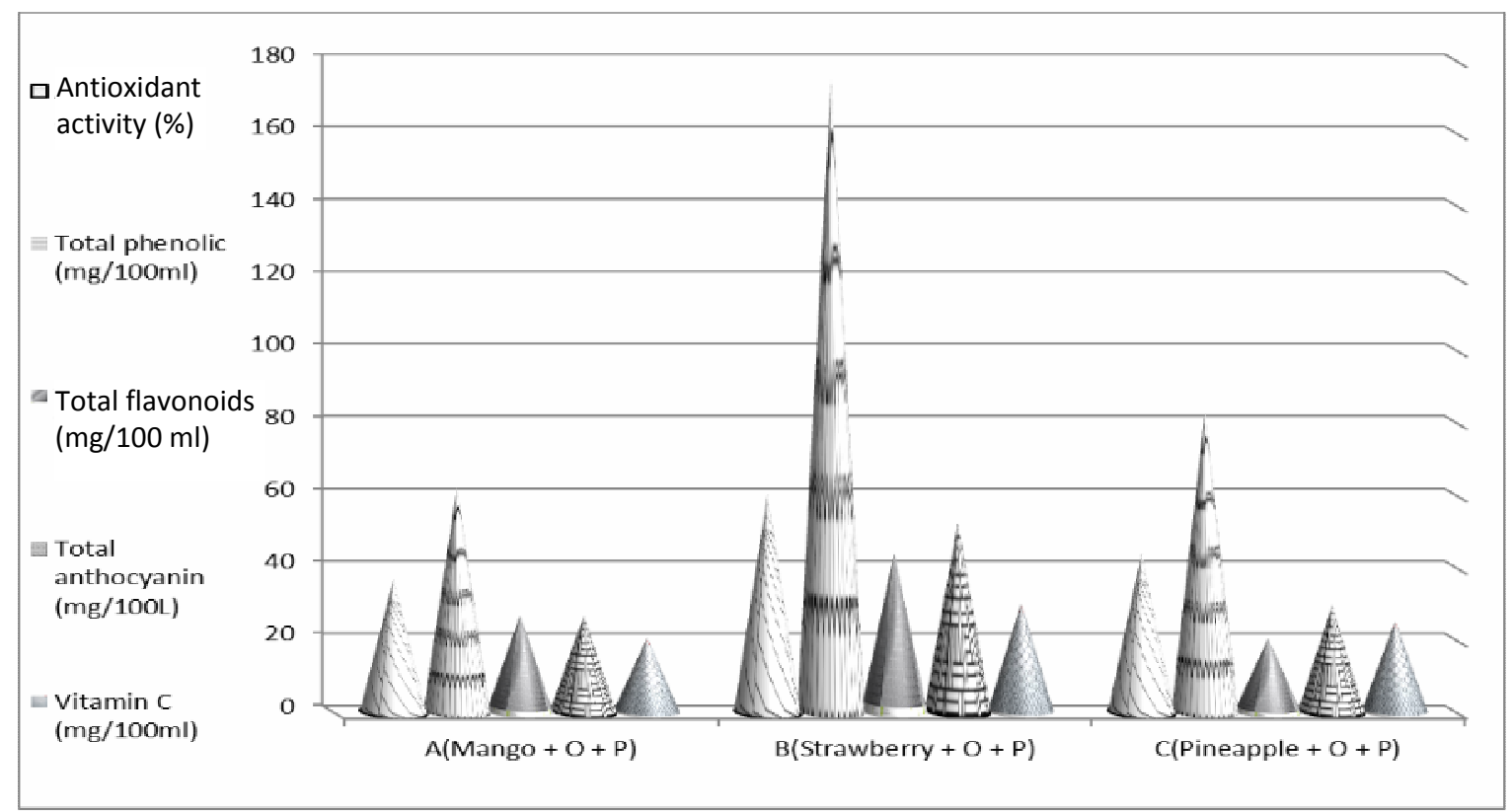

Fig. 4. Phytochemical content of mixes fresh juices 
compared to those in the non-pasteurized juice. The maximum decrease in total phenol content was observed in treatment, T4, T5, T6 and T7, it gave values $84.38,82.43,78.80$ and $98.81(\mathrm{mg} /$ $100 \mathrm{ml}$ ), respectively compared to the fresh juice mixes.

Previous studies have shown that the effect of thermal treatments on total phenolic concentrations is variable. For example, the total phenolic content of a mango juice treated at $90^{\circ} \mathrm{C}$ for 60 sec., was reduced by $38 \%$ Santhirasegaram et al. (2013). But no significant alteration in the total phenolic concentration was evident for peach pieces pasteurized at $90^{\circ} \mathrm{C}$ for 5 min, Oliveira et al. (2012). This variability confirms that the effect of thermal treatment depends on the severity of the heat process, the specific factors that are characteristic of the food matrix and the sensitivity of the different phytochemicals to temperature Rawson et al. (2011).

Concerning storage of the juices at cooled temperatures increased the total phenolic content toward the end of storage period for all juices mixture. It was found that the increase ratios in the total phenolic content in the treatments $\mathrm{T} 4$ to T7 ranged from 33.86 to $42.27 \%$ followed by treatment T1toT3 and the rate of increase was from 14.28 to $27.48 \%$. Finally, less treatments in this ratio were in $\mathrm{T} 8$ to $\mathrm{T} 10$ and the increase ranged between 5.57 to $13.71 \%$.

This observation is supported by the findings of Klimczak et al. (2007) who reported that the total phenols of orange juice increased significantly at the end of 6 months ${ }^{\text {ee }}$ storage time. Another similar finding was reported by Tavarini et al. (2008) who found that the phenols in kiwi fruits remained stable during the initial 2 months of storage at $0^{\circ} \mathrm{C}$ and increased significantly after 6 months of storage. It has been reported that there is a direct relationship between the phenolic content and antioxidant capacity of plants. Similar behaviors were observed in grape fruit juice (Igual et al., 2010).

In the same Table, significant variation in antioxidant activity (\%) in juice mixes after pasteurization were observed and the values ranged from 55.47 to $96.44 \%$ in all treatment. It could be seen that the highest level of antioxidant activity (\%) obtained in treatments $\mathrm{T} 1, \mathrm{~T} 2, \mathrm{~T} 4, \mathrm{~T} 5$ and $\mathrm{T} 7$. The results were $96.44 \%, 92.38 \%, 84.25,82.37$ and $81.90 \%$, respectively and the lowest values were in treatment $\mathrm{T} 3$ and $\mathrm{T} 10$ and valued 59.72 and $55.47 \%$. The evident higher antioxidant activity (\%) after processing in treated juice mixture with microwave pasteurizationat two power levels comparison with conventional processing. Similar effects have been reported for the studies involving the non-ionizing radiation treatment of broccoli florets where it was shown that the antioxidant capacity of broccoli increased during the treatment (Costa et al., 2006; Lemoine et al., 2007).

Significant decrease was noted in antioxidant activity (\%) after storage in pasteurization juice mixture in both methods. The decrease in antioxidant activity (\%) ranged between $22 \%$ to $41 \%$ in treatments containing mango juice and $19 \%$ to $39 \%$ in treatments containing pineapple juice. Otherwise antioxidant activity (\%) found to be stable in treatments $\mathrm{T} 4, \mathrm{~T} 6$ and $\mathrm{T} 7$, with the exception of treatment $\mathrm{T} 5$. The presented results are in line with the results obtained by Klimczak et al. (2007). They found that the decreases in antioxidant capacity of orange juice, after 6 months of storage at 18, 28 and $38^{\circ} \mathrm{C}$ were $18 \%, 45 \%$ and $84 \%$, respectively. However, microwave and conventional pasteurization caused a similar decrease of the total phenol content and DPPH values. Microwave processing of kiwi fruit puree has also been found to result in significantly higher antioxidant activity compared to conventional heat treatment (Benlloch-Tinoco et al., 2014).

The total flavonoids content of the nontreated mixes juice mentioned in the Table 6 with pasteurisation treatment decrease in all treatment and ranged between 13.06 to $37.39(\mathrm{mg} / 100 \mathrm{ml})$ compared with non treated. On the other hand, slightly increase in total flavonoids content in storage was observed. Sanchez-Moreno et al. (2005) showed that flavonone concentration of orange juice increased with $\mathrm{PEF}$ and thermal pasteurisation at $70^{\circ} \mathrm{C}$ for $30 \mathrm{sec}$. However, its concentration decreased when orange juice was treated with high thermal pasteurisation at $90^{\circ} \mathrm{C}$ for $60 \mathrm{sec}$. 
Table 6. Effect of pasteurization process and storage on the antioxidant, total phenolic content and total flavonoid content on mixture juices

\begin{tabular}{ccccccc}
\hline Treatment & $\begin{array}{c}\text { Antioxidant } \\
\text { activity } \\
\text { (\%) after } \\
\text { processing }\end{array}$ & $\begin{array}{c}\text { Antioxidant } \\
\text { activity } \\
\text { (\%) after } \\
\text { storage }\end{array}$ & $\begin{array}{c}\text { Total } \\
\text { phenolic } \\
\text { compounds } \\
\text { (mg/100ml) } \\
\text { after processing }\end{array}$ & $\begin{array}{c}\text { Total } \\
\text { phenolic } \\
\text { compounds } \\
\text { (mg/100ml) } \\
\text { after storage }\end{array}$ & $\begin{array}{c}\text { Total } \\
\text { flavonoids } \\
\text { (mg/100ml) }\end{array}$ & $\begin{array}{c}\text { Total } \\
\text { flavonoids } \\
\text { (mg/100ml) }\end{array}$ \\
\hline T1 & 96.44 & 65.57 & 51.29 & 72.52 & 18.69 & 19.21 \\
T2 & 92.38 & 54.46 & 48.31 & 66.05 & 19.21 & 19.72 \\
T3 & 59.72 & 46.30 & 52.59 & 56.36 & 15.62 & 26.38 \\
T4 & 84.25 & 84.18 & 84.38 & 149.17 & 35.60 & 37.39 \\
T5 & 82.37 & 71.30 & 82.43 & 140.80 & 37.39 & 39.95 \\
T6 & 74.67 & 74.33 & 78.80 & 119.15 & 32.78 & 33.29 \\
T7 & 81.90 & 81.42 & 98.81 & 157.32 & 39.95 & 40.97 \\
T8 & 71.63 & 43.27 & 81.22 & 86.01 & 14.98 & 27.91 \\
T9 & 66.50 & 41.73 & 76.75 & 86.15 & 13.06 & 20.23 \\
T10 & 55.47 & 44.51 & 73.82 & 85.55 & 13.70 & 21.01 \\
\hline
\end{tabular}

T1- $40 \%$ mango, $30 \%$ orange, $30 \%$ pomegranate.

T3- $40 \%$ mango, $30 \%$ orange, $30 \%$ pomegranate.

T5- $40 \%$ strawberry, $30 \%$ orange, $30 \%$ pomegranate.

T7- $40 \%$ strawberry, $30 \%$ orange, $30 \%$ pomegranate.

T9- $40 \%$ pineapple, $30 \%$ orange, $30 \%$ pomegranate.
T2- $40 \%$ mango, $30 \%$ orange, $30 \%$ pomegranate.

T4- $40 \%$ strawberry, $30 \%$ orange, $30 \%$ pomegranate.

T6- $40 \%$ strawberry, $30 \%$ orange, $30 \%$ pomegranate.

T8- $40 \%$ pineapple, $30 \%$ orange, $30 \%$ pomegranate.

T10- $40 \%$ pineapple, $30 \%$ orange, $30 \%$ pomegranate

\section{Microbiological Results for Mixes Fruit Juices}

Results from microbiological tests showed no presence of viable microorganisms (total count, mold and yeast) after storage in all treatments. Tajchakavit et al. (1998) indicated that MW treatment is effective in reducing the $\mathrm{TAB}$ in different fruit products. Inactivation of aerobic bacteria by MW treatment is thought to be the result of protein denaturation and aggregation in cytoplasm indicated by dark spots and the leakage of nucleic acids.

Effects of juice processing on total anthocyanins and ascorbic acid

The anthocyanins content of strawberry fresh juice and pomegranate fresh juice were 111.12 and $87.68 \mathrm{mgl}$, respectively (data not shown) while the anthocyanins content of mixture of fresh juices is shown in Fig. 4.
The anthocyanins content of juices mixture after processing and storage are obtained in Table 8, from the lowest levels of anthocyanins content were found in the pasteurized juices compared to those in nonpasteurized juice. Anthocyanins have been described as molecules that are more sensitive to decomposition during thermal processes than other non-anthocyanin, polyphenolic compounds (Piasek et al., 2011; Mena et al., 2013). The degradation rate increased at higher temperatures, increase the time which suggested that high temperature accelerated the anthocyanin degradation (Kirca et al., 2007). The lowest degradation rate value of anthocyanins was for microwave followed by thermal pasteurized.

Results showed that highest anthocyanin content were in treatments $\mathrm{T} 7, \mathrm{~T} 4, \mathrm{~T} 5$ and $\mathrm{T} 6$ which were 40.99, 38.19, 35.21 and $29.61 \mathrm{(mg} /$ $100 \mathrm{ml}$ ), respectively than other treatment 
Table 7. Microbiological results for mixture fruit juices

\begin{tabular}{cccc}
\hline Treatment & Total plate count $(\mathbf{C f u} / \mathbf{m l})$ & Mold $(\mathbf{C f u} / \mathbf{m l})$ & Yeast $(\mathbf{C f u} / \mathbf{m l})$ \\
\hline T1 & ND & ND & ND \\
T2 & ND & ND & ND \\
T3 & ND & ND & ND \\
T4 & ND & ND & ND \\
T5 & ND & ND & ND \\
T6 & ND & ND & ND \\
T7 & ND & ND & ND \\
T8 & ND & ND & ND \\
T9 & ND & ND & ND \\
T10 & ND & ND & ND \\
\hline
\end{tabular}

$\mathrm{ND}=$ Not detected

Table 8. Effects of juice processing on total anthocyanins and ascorbic acid

\begin{tabular}{ccccc}
\hline Treatment & $\begin{array}{c}\text { Total anthocyanin } \\
\text { (mg/100ml) after } \\
\text { processing }\end{array}$ & $\begin{array}{c}\text { Total anthocyanin } \\
\text { (mg/100ml) after } \\
\text { storage }\end{array}$ & $\begin{array}{c}\text { L- Ascorbic acid } \\
\text { (mg/100ml) after } \\
\text { processing }\end{array}$ & $\begin{array}{c}\text { L- Ascorbic aci } \\
\text { (mg/100ml) after } \\
\text { storage }\end{array}$ \\
\hline T1 & 25.11 & 22.33 & 17.10 & 13.22 \\
T2 & 21.53 & 19.42 & 15.32 & 12.65 \\
T3 & 18.60 & 15.34 & 4.88 & 3.33 \\
T4 & 38.19 & 35.32 & 28.76 & 23.24 \\
T5 & 35.21 & 32.71 & 26.54 & 22.12 \\
T6 & 29.61 & 25.72 & 8.34 & 5.23 \\
T7 & 40.99 & 36.91 & 29.32 & 22.99 \\
T8 & 23.01 & 20.65 & 22.63 & 18.44 \\
T9 & 21.80 & 19.72 & 20.33 & 18.01 \\
T10 & 17.68 & 14.56 & 6.25 & 3.65 \\
\hline
\end{tabular}


because that contain a mixture of strawberries and pomegranates juices. However, anthocyanin content in all treatments was greater in microwave compared to thermal pasteurized after processing and storage. Anthocyanin content decreased by $17.52 \%, 13.14 \%$ and $17.64 \%$ in treatment $\mathrm{T} 3, \mathrm{~T} 6$ and $\mathrm{T} 10$, respectively after storage in thermally processed juice comparatively, anthocyanin content of microwave reduced between 7.10-11.07\% during the same storage period

Ascorbic acid content of fresh juices mixture before processing are shown in Fig. 4. It could be seen that the highest content in ascorbic acid in mixture juices (treatment B) followed by (treatment $\mathrm{C}$ ) and (treatment A), respectively. While ascorbic acid content after pasteurized juices present in Table 8 , Vitamin $\mathrm{C}$ content was in the range of 4.88 to $29.32 \mathrm{mg} / 100 \mathrm{ml}$. The highest Vitamin $\mathrm{C}$ content was recorded in treatment T4 $(29.32 \mathrm{mg} / 100 \mathrm{ml})$ while, minimum Vitamin $\mathrm{C}$ content was found in treatment T3 $(4.88 \mathrm{mg} / 100 \mathrm{ml})$. The thermal processing leads to a significant degradation in the ascorbic acid content. After thermal processing degradation was found different rates ranging 21.89 to $81.19 \%$. Further it was reduced ranging 36.75 to $88.70 \%$ during storage. Our results are in accordance with Odriozola-Serrano et al. (2009) who studied the Vitamin C losses in orange and strawberry juices.

Vitamin $\mathrm{C}$ content decreased sharply during the storage presumably, due to the complete degradation of L-ascorbic acid while the dehydro ascorbic acid can still be maintained in the juice. Choi et al. (2002) found similar results when they studied the ascorbic acid retention in blood orange juice during refrigerated storage. The researchers found, that the L-ascorbic acid completely degraded within 5 weeks.

In the present study, the reduction of vitamin $\mathrm{C}$ content stored at 3months and at $4-{ }^{\circ} \mathrm{C}$ in mixture juices were $47.21 \%, 40.85 \%$ and $39.94 \%$, in $\mathrm{T} 1, \mathrm{~T} 2$ and $\mathrm{T} 3$, respectively. The decrease in vitamin $\mathrm{C}$ content during storage was observed by many studies Klimczak et al. (2007) and Piljac-Zegarac et al. (2009). The vitamin $\mathrm{C}$ content in the juice decreased during storage is dependent on the storage conditions such as temperature, oxygen, and light.

The conventionally pasteurized juice presented the lowest, statistically significant ascorbic acid content. In this sense, the obtained results were the expected ones, since according to Vadivambal and Jayas (2007), ascorbic acid retention is superior in the microwave treatment than in the traditional one. In this respect, in order to diminish the impact on quality provoked by processing the juice, it would be preferable to apply microwave pasteurization since a greater proportion of this compound is preserved.

\section{Conclusions}

Mixture different juices pasteurization with the novel industrial microwave system had higher most physicochemical characteristics such as antioxidant capacity, anthocyanins content, ascorbic acid content compared with the conventional pasteurization after processing. Microwave processing appears to a viable alternative for mixture juice pasteurization since it can produce a physicochemically and microbiologically stable product and significantly reduced processing time. The application of new generation microwave technologies in food processing has not reached its full potential so far, however, it shows promise in delivering a range of products and ensuring microbiological safety without compromising quality.

Finally, it could be clearly concluded that it is applicable, economic and hence successful to produce new untraditional juices mixes of different fruits. This would lead to achieve high nutritional values products plus having high palatable organoleptic properties. Hence phelosphy of mixing juices.

\section{REFERENCES}

Ahsen, R. and T. Baysal (2011). Yield and quality effects of electroplasmolysis and microwave applications on carrot juice production and storage. J. Food Sci.76,4.

Ahuja, J.K.A., J.B. Montville, G. OmolewaTomobi, K.Y. Heendeniya, C.L. Martin, L.C. Steinfeldt, J. Anand, M.E. Adler, R.P. LaComb and A.J. Moshfegh (2012). USDA Food and Nutrient Database for Dietary Studies, 5.0. US. Agric. Dept., Agric. Res. Serv., Food Surveys Res. Group, Beltsville, MD. 
Akash, S.R., B.R. Shakya and D.A. Kuldip (2014). Studies on effect of thermal processing on preparation of Bael Fruit RTS blended with Aonla. Int. J. Res. Eng. and Adv. Technol., 2 : 1-6.

Akhter, S., S. Masood, S.H. Jadoon, I. Ahmad and S. Ullah (2012). Quality evaluation of different brands of Tetra Pak mango juices available in market. Pak. J. Food Sci., 22: 96-100.

AOAC. (2012). Association of Official Analytical Chemists. Official Methods of Analysis Association of Official Analytical Chemists int., $19^{\text {th }}$ Ed., Gaithersburg, Maryland, 20877- 2417.USA.

Awsi, J. and M.Er. Dorcus (2012). Development and quality evaluation of pineapple juice blend with carrot and orange juice', Int. J. Scientific and Res. Publications, $2: 8$.

Benlloch-Tinoco, M., M. Igual, A. Salvador, D. Rodrigo and N. Martnez-Navarrete (2014). Quality and acceptability of microwave and conventionally pasteurised kiwi fruit puree. Food and Bioprocess Technol., 7 : 32823292.

Borowska, E.J., B. Mazur and R.B. GadzalaKopciuch (2009). Polyphenol, anthocyanin and resveratrolmass fractions and antioxidant properties of cranberry cultivars. Food Technol. Biotechnol., 47: 56-61.

Bull, M.K., K. Zerdin, E. Howe, D. Goicoechea, P. Paramanandhan, R. Stockman, J. Sellahewa, E.A. Szabo, R.L. Johnson and C.M. Stewart (2004). The effect of high pressure processing on the microbial, physical and chemical properties of Valencia and Navel orange juice. Innovative Food Science and Emerging Technol., 5: 135-149.

Campos, F.M., J.B.P. Chaves, R.M.C.D. Azeredo, G.M.S.C. Mata and H.M. PinheiroSantana (2010). Adequate handling conditions to preserve vitamin-C and carotenoids in tomatoes. J. Food Qual., 3 3: 230-245.

Caoumir, J.A., J.E. Celis, J. Brujin and L. Vidal (2002). Pasteurisation of apple juice by using microwaves. Lebensmittel-Wissenschaft und Technol., 35: 389-392.
Cassano, A., E. Drioli, G. Galaverna, R. Marchelli and G. Di-Silvestra (2003). Clarification and concentration of citrus and carrot juices by integrated membrane processes. J. Food Eng., 57: 153-163.

Chang, C., M. Yang, H. Wen and J. Chern (2002). Estimation of total flavonoid content in propolis by two complementary colorimetric methods. J. Food and Drug Anal., 10:178-182.

Choi, M.H., G.H. Kim and H.S. Lee (2002). Effect of ascorbic acid retention on juice colour and pigment stability in blood orange (Citrus sinensis) juice during refrigerated storage. Food Res. Int., 35: 753-759.

Costa, A.R., P.M. Vicente, A.R. Civello and G.A. Chaves (2006). Martinez, UV-C treatment delays postharvest senescence in broccoli florets, Posthar. Biol. Technol., 39: 204-210.

Cullen, P.J., V.P. Valdramidis, B.K. Tiwari, S. Patil, P. Bourke and C.P. O'Donnell (2010). Ozone processing for food preservation: an overview on fruit Juice treatments. Ozone Sci. Eng., 32: 166-179.

De Carvalho, J.M., G.A. Maia, R.W.D. Figueiredo, E.S.D. Brito and S. Rodrigues (2007). Development of a blended non alcoholic beverage composed of coconut water and cashew apple juice containing caffeine. J. Food Qual., 30: 664- 681.

Dharti, P.1. and P. Dhvanika (2014). Development and evolution of antioxidant rich fruit beverage. Int. J. Food Sci. Nut. Diet., 3 (9): 160-163.

Emy, N.E., B. Corinne, A. Sandra and R. Katia, (2015). Polyphenols, carotenoids, vitamin C content in tropical fruits and vegetables and impact of processing methods. Food and Nut. Sci., 6: 299-313.

Fuglie, L.G. (2001). The miracle tree.The multiple attributes of Moringa. CTA, Publishing Company Inc. Wageningen, Netherlands, $668-749$.

Gerard, K.A. and J.S. Roberts (2004) Microwave heating of apple mash to improve 
juice yield and quality. Lebensm Wissb Technol., 37 :551-7.

Hong, M.Y., N.P. Seeram and H. Heber (2008) Pomegranate polyphenols downregulate expression of androgen-synthesizing genes in human prostate cancer cells overexpressing the androgen receptor. J. Nut. Biochem., 19: 848-855.

Hossain, M.A. and S.M.M. Rahman (2011). Total phenolics, flavonoids and antioxidant activity of tropical fruit pineapple. Food Rese. Int., 44: 672-676.

Hung, P.V. and N. Morita (2009). Distribution of phenolic compounds in the graded flours milled from whole buckwheat grains and their antioxidant capacities. Food Chem., 109: 325-331.

Igual, M., E. García-Martínez, M.M. Camacho and N. Martínez-Navarrete (2010). Effect of thermal treatment and storage on the stability of organic acids and the functional value of grapefruit juice. Food Chem., 118: 91-299.

Kirca, A.O., M. Zkan and B. Cemerog lu (2007). Effects of temperature, solid content and $\mathrm{pH}$ on the stability of black carrot anthocyanins. Food Chem., 101(1): 212-218.

Klimczak, I., M. Malecka, M. Szlachta and A. Gliszcynska (2007). Effect of storage on the content of polyphenols, vitamin $\mathrm{C}$ and the antioxidant activity of orange juice. J. Food Comp. and Anal., 20: 313-322.

Lemoine, M.L., P.M. Lemoine, G.A. Civello and A.R. Martnez (2007). Influence of postharvest UV-C treatment on refrigerated storage of minimally processed broccoli (Brassica Oleracea var. Italica), J. Sci. Food Agric., 87 : 1132-1139.

Manoj, M., R.G. Chaves and N. Tajendra (2014). Studies on bio- chemical composition of orange based blended ready- to- serve (RTS) beverages. Biosci. Biotech. Res. Comm., 7 (1): 78-83.

Mena, P., S. Vegara, N. Martı', C. Garc1'aViguera, D. Saura and M. Valero (2013). Changes on indigenous microbiota, color, bioactive compounds and antioxidant activity of pasteurized pomegranate juice. Food Chem., 141 (3): 2122-2129.

Mhatre, M., J. Tilak-Jain, S. De and T.P.A. Devasagayam (2009). Evaluation of antioxidant activity of non-transformed and transformed pineapple: A comparative study. Food and Chem. Toxicol., 47: 2696-2702.

Mustafa, H.S.G. and M.Ö. Mehmet (2012). Comparative evaluation of some macro- and micro-element and heavy metal contents in commercial fruit juices. Environ. Monit. Assess., 184 : 5415-5420.

Odriozola-Serrano, I., R.C. Soliva-Fortuny, and O. Martín-Belloso (2009). Impact of highintensity pulsed electric fields variables on vitamin $\mathrm{C}$, anthocyanins and antioxidant capacity of strawberry juice. LWT- Food Sci. and Techno., 42: 93-100.

Ohwesiri, M.A., B.K.K. David and O.E. Caroline (2016). Quality characteristics of orange/pineapple fruit juice. Ame. J. Food Sci. and Technol., 4 (2): 43-47.

Oliveira, A., M. Pintado and D. Almeida (2012). Phytochemical composition and antioxidant activity of peach as affected by pasteurization and storage duration. LWTFood Sci. and Technol., 49: 202-207.

Piasek, A., B. Kusznierewicz, I. Grzybowska, E. Malinowska-Panczyk, A. Piekarska, A. Azqueta, A. Collins, J. Namiesnic and A. Bartoszek (2011). The influence of sterilization with EnbioJet Microwave flow pasteurizer on composition and bioactivity of aronia and blue-berried honeysuckle juices. J. Food Comp. and Anal., 24: 880-888.

Piljac-Zegrac, J., L. Valek, S. Martinez, and A. Belscak (2009). Fluctuations in the phenolic content and anitioxidant capacity of dark fruit juices in refrigerated storage. Food Chem., 113: 394-400.

Punna, R. and U.R. Paruchuri (2003). Total, insoluble and soluble dietary fiber contents of Indian. J. Food Comp. and Anal., 16: 677685.

Rawson, A., A. Patras, B. Tiwari, F. Noci, T. Koutchma and N. Brunton (2011). Effect of thermal and non-thermal processing 
technologies on the bioactive content of exotic fruits and their products: review of recent advances. Food Res. Int., 44 : 18751887.

Riahi, E. and H.S. Ramaswamy (2004). High pressure inactivation kinetics of amylase in apple juice. J. Food Eng., 64: 151-160.

Rivas, A., D. Rodrigo, A. Martinez, G.V. Barbosa-Canovas and M. Rodrigo (2006). Effect of PEF and heat pasteurization on the physical-chemical characteristics of blended orange and carrot juice. J. Food Sci. and Technol., 39: 1163-1170.

Robert, W.D. and R.E. Wrolstad (2005). Determination of total monomeric anthocyanin pigment content of fruit juice, beverages, natural colorants, and wines by the $\mathrm{pH}$ differential method: collaborative study: J. AOAC Int., 88:1269-1278.

Sanchez-Moreno, C., L. Plaza, P. Elez-Martinez, B. De Ancos, O. Martin-Belloso and M.P. Cano (2005). Impact of high pressure and pulsed electric field on bioactive compounds and antioxidant activity of orange juice in comparison with traditional thermal processing. J. Agric. and Food Chem., 53: 4403-4409.

Santhirasegaram, V., Z. Razali and C. Somasundram (2013). Effects of thermal treatment and sonication on quality attributes of Chokanan mango (Mangifera indica L.) juice. Ultrasonic Sonochem., 20 (5): 12761282.

Singleton, V.L., R. Orthofer and R.S. LamuelaRaventós (1999). Analysis of total phenols and other oxidation substrates and antioxidants by means of Folin- Ciocalteau Reagent. Methods Enzymol., 299:152-178.

Tajchakavit, S., H.S Ramaswamy and P. Fustier (1998). Enhanced destruction of spoilage microorganism in apple juice during continuous flow microwave heating. Food Res. Int., 31 (10): 713-722.

Tandon, K., R.W. Worobo, J.J. Churey and O.I. Padilla-Zakour (2003). Storage quality of pasteurized and UV treated apple cider. J. Food Proc. and Preservation, 27: 21-35.

Tavarini, S., E.D. Innocenti, D., Remorini, R. Massai and L. Guidi (2008). Antioxidant capacity, ascorbic acid, total phenols and carotenoids changes during harvest and after storage of Hayward kiwi fruit. Food Chem., 107: 282-288.

Vadivambal, R. and D.S. Jayas (2007). Changes in quality of microwave-treated agricultural products. A review. Biosystems Eng., 98: 116.

Yeom, H.W., C.B. Streaker, Q.H. Zhang and D.B. Min (2000). Effects of pulsed electric fields on the quality of orange juice and comparison with heat pasteurization. J. Agric. and Food Chem., 48: 4597-4605. 


\title{
تقييم الخصائص الفيزيائية والكيميائية لبعض مخاليط العصائر
}

\author{
سهيز السيد مصطفي سعد \\ قسم بحوث تكنولوجيا الحاصلات البستانية ـ معهد بحوث تكنولوجيا الأغذية ـ مركز البحوث الزر اعية ـ الجيزة ـ مصر
}

أجريت هذه الدراسة لبحث تحسين وتطوير خليط من عصائر الفاكهة تم أعدادها من المانجو والفراولة والأناناس

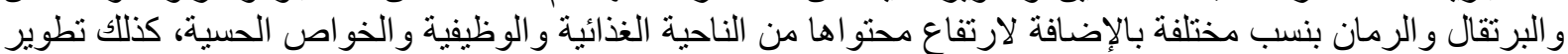

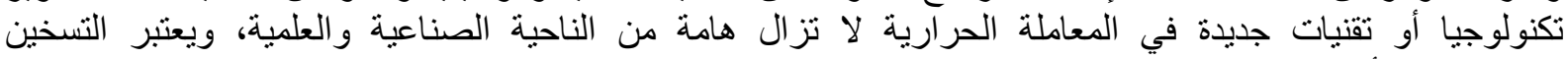
بالميكروويف أحدي هذه التكنولؤجيات الجديدة حيث فيث يتم بسترة خليط عصائر الفاكهة بطريقتين مختلفتين وهما المعاملة

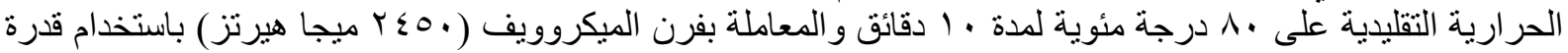

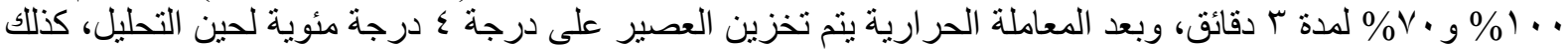

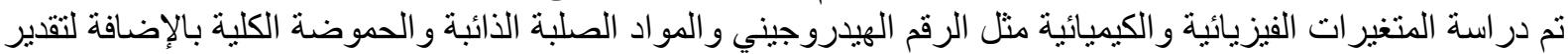

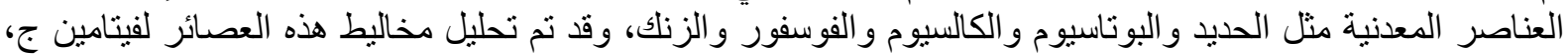

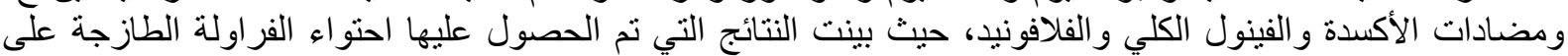

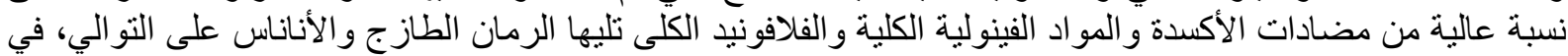

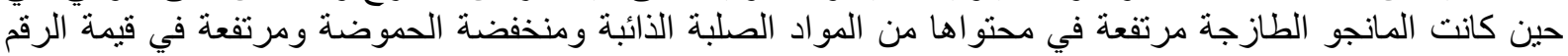

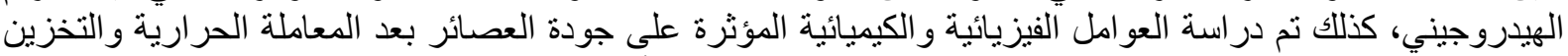

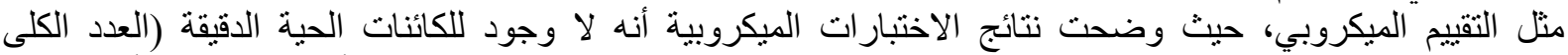

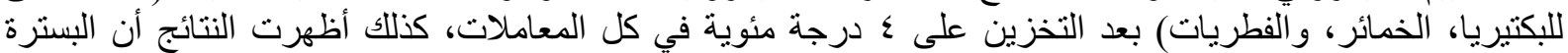

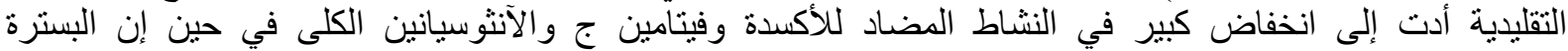

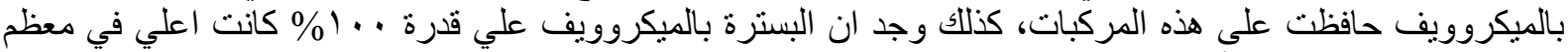

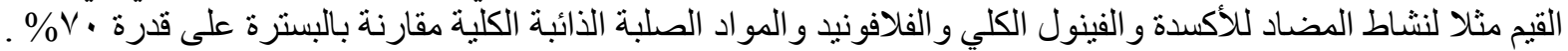

